\section{SOCIETIES AND ACADEMIES.} LoNDON.

Royal Society, November 19, I903.-"On the Nematocysts of Akolids." By G. H. Grosvenor, New College, Oxford. Communicated by Prof. W. F. R. Weldon, F.R.S.

The nematocysts of æolids were discovered by Alder and Hancock in 1843 . As early as $185^{8}$ Strethill Wright communicated to the Royal Phys. Soc. of Edinburgh the results of some observations which seemed to prove that these nematocysts were not developed in the body of the zolid, but derived from its colenterate prey. This paper, though republished in the Microscopical Journal four years later, seems to have been entirely overlooked, and the nematocysts of nudibranchs have been generally supposed to be developed in situ, and have often been quoted as an inexplicable example of homoplasy or even as evidence of a close relationship between Mollusca and coelenterates. C O. Glaset has, however, recently supported the opposite view.

The evidence brought forward in the present paper in support of Strethill Wright's view is as follows :-

(I) Not only are the nematocysts of xolids and colenterata identical in plan and in mode of discharge, but each of several distinct types occurs in both groups.

(2) The nematocysts of æolids vary from individual to individual within the species, and even in the same individual there may be nematocysts characteristic of two or more distinct genera or families of cœlenterates.

(3) Whenever it is known on what cœlenterate an æolid has recently fed, the nematocysts of the two are found to be identical. Also the nematocysts in the fæces are always indistingu shable from one of the kinds, at least, in the cnidosac.

(4) Those æolids (Janidæ, Fiona, and Calma glaucoides) which are known to feed on non-cœlenterate prey have no nematocysts.

(5) Nematocysts and other indigestible bodies have been observed to pass through the ciliated canal from the cavity of the gastric gland into the cnidosac.

(6) Strethill Wright's most conclusive evidence was derived from an experiment of feeding an zolid on a hydroid with nematocysts different from those in the cnidosacs of the xolid. This experiment has been repeated several times, always with the result that the new nematocysts very soon appeared in the cnidosacs of the rolid. In one case three specimens of Rizzolia peregrina, with only small pip-shaped nematocysts $(6.5 \mu)$ in their cnidosacs, were fed on Pennaria Cavolinii, a hydroid with very distinct ovoid nematocysts of two sizes $(25 \mu$ and $7 \mu$ ). After about a month of this diet the pip-shaped nematocysts were almost entirely replaced by those of Pennaria. These latter were enclosed in cnidocysts in the ordinary way.

Though the nematocysts of reolids are derived from their food, they discharge the threads on extrusion from the cerata into sea-water, and there can be little doubt that they are used as weapons of defence. But an important, and probably the original function of the terminal openings of the cerata is the elimination of the indigestible nematocysts, which, on account of the diffuse character of the digestive "wstem, cannot easily be got rid of through the anus onl

The face of their discharge when extruded naked into th: sea-water from the cnidosacs of an æolid proves that nematocysts work without the intervention of living protoplasm. A study of the conditions of discharge of nematocysts in cœlenterates and xolids, and of their behaviour in various solutions, leads to the conclusion that we have t) do with a phenomenon of osmosis.

In the development of the cnidocysts two kinds of cells take part; one, the so-called "cnidoblast," ingests and arranges the nematocysts, while others lying between adjacent cnidocysts take part in the secretion of the membranous walls. Both kinds degenerate in the fully formed cnidocyst.

December 13, 1903.- "Preliminary Note on the Resistance to Heat of B. anthracis." By A. Mallock, F.R.S. and Lieut.-Colonel A. M. Davies.

This paper describes a series of experiments made by heating water infected with anthrax to various temperaNO. I 784 , vOL. 69] tures for various times, in order to determine the temperature and time necessary for the destruction of the spores.

The infected water was sealed in glass tubes and heated in steam in an apparatus which was designed so that any desired temperature could be maintained and simultaneously recorded.

The highest temperature employed was $120^{\circ} \mathrm{C}$. and the lowest $99^{\circ}$

The longest time for which the temperature was maintained was twenty minutes, and the shortest twenty seconds.

From statements made by good authorities as to the great heat resisting power of the spores of anthrax, it was expected that the temperature required to destroy the spores, when expressed as a function of the time for which the temperature had to be maintained, would form a curve, the temperature decreasing as the time of its application increased.

The authors, however, found that out of 95 experiments in which the tubes were heated to $100^{\circ} \mathrm{C}$. or more, in $8 \mathrm{r}$ all life was destroyed, and out of the remaining i4 experiments, in which some growth took place after cultivation in broth, 12 had become contaminated. After heating is experiments were made at temperatures between $99^{\circ} \mathrm{C}$. and $100^{\circ} \mathrm{C}$. In 5 of these experiments some growth occurred after cultivation, 4 of these being found contaminated.

The conclusion arrived at is that when anthrax spores are heated in water to $100^{\circ} \mathrm{C}$. or more, even for twenty or thirty seconds, their destruction is almost certain.

Chemica: Society, December 16, 1903.-Prof. W. A. Tilden, F.R.S., president, in the chair.-The following papers were read:-The relative strengths of the alkaline hydroxides and of ammonia as measured by their action on cotarnine, by Messrs. Dobbie, Lauder and Tinkler. When aqueous solutions of cotarnine are treated with alkaline hydroxides or ammonia the alkaloid is changed from the "ammonium hydroxide" form to the "carbinol" form. As solutions of these two forms of cotarnine exhibit very different absorption spectra, it is possible by this means to observe the rates at which this change is brought about by different alkalis. The relative strengths of the alkaline hydroxides as determined by this method are practically identical with those obtained by other physical methods. -Peroxylaminesulphonates and hydroxylaminetrisulphonates, by Mr. T. Haga.-An investigation of the sulphazilates and metasulphazilates first obtained by Fremy. Peroxylaminesulphonic acid, by Dr. E. Divers. The author shows that the bluish-violet substance produced by the action of sulphur dioxide on sulphuric acid containing nitrososulphuric acid is probably, as has already been asserted by Sabatier, peroxylaminesulphonic acid, the potassium salt of which is described in the preceding paper. -Constitution of nitric peroxide, by Dr: E. Divers. It is shown from the results of Haga's investigations that the mono-nitric peroxide must have the formula O : N.O, whilst the dinitric peroxide must have the constitution ( $\mathrm{NO})_{2} \mathrm{O}_{2}$. --Halogen derivatives of diphenyl and dihydroxydiphenyl, by Mr. J. C. Cain.-Notes on some natural colouring matters, by Messrs. A. G. Porkin and E. Phipps. The flowers of Prunus spinosa contain the two colouring matters quercetin and kampherol. The Japanese dye-stuff "Fukugi" contains a yellow substance closely related. to luteolin. A number of derivatives of morin, hesperitin, myricetin and curcumin are also described.-The estimation of methyl alcohol in the presence of ethyl alcohol, by Messrs. T. E. Thorpe and J. Holmes. The method is based upon the difference in behaviour of these two alcohol towards a mixture of potassium dichromate and sulphuric acid.-Separation and estimation of silver cyanide and silver chloride, by Mr. R. H. A. Plimmer. The mixture is treated with boiling dilute nitric acid, and the hydrocyanic acid so liberated distilled off and estimated as silver cyanide. -Estimation of hydroxyl radicles, by Messrs. H. Hibbert and $J . J$. Sudborough. A modification of Tschugaeff's method is described.-Diortho-substituted benzoic acids, part v., formation of salts from diortho-substituted benzoic acids and organic bases, by Messrs. J. J. Sudborough and W. Roberts.-Cis- $\pi$-camphanates of $d$ - and $l$-hydrindamines, by Prof. F. S. Kipping.-Resolution of $d l$-methylhydrindamine, by Mr. G. Tattersall,-Isomeric salts of $d$ - and 
l-methylhydrindamines with $d$-chlorocamphorsulphonic acid, by Mr. G. Tattersall. - The four optically isomeric $l$-menthylamines and their salts, by Messrs. F. Tutin and F. S. Kipping.-Preparation of the tetra-alkyl derivatives of stannimethane, by Messrs. W. J. Pope and S. J. Peachey. The authors have prepared a number of these derivatives by the interaction of magnesium alkyl haloids with stannic chloride or alkyl derivatives of the latter.-Optically active esters of $\beta$-ketonic and $\beta$-aldehydic acids, part iv., condensation of aldehydes with menthyl acetoacetate, by Messrs. A. C. O. Hann and A. Lapworth.-Estimation of the adulterant in citronella oil, by Mr. M. K. Bamber.

Geologica. Society, December 16, 1903.-Sir Archibald 'reikie, Sec.R.S., vice-president, in the chair.-The igneous rocks associated with the Carboniferous Limestone of the Bristol district, by Prof. C. Lloyd Morgan, F.R.S., and Prof. Sidney H. Reynolds. Evidence for the contemporaneous origin of the igneous rocks is given for several localities. At Middle Hope the ejectamenta thin to the east, and lava is only found to the west; at Spring Cove, near Westonsuper-Mare, small lapilli were found in the limestone 8 feet above the basalt. At Goblin Combe there is the most characteristic section of ashy beds; the lenticular bands of greenish tuff, the limestone-intercalations, the admixture of lapilli, limestone fragments, and oolitic grains are stamped with the mark of submarine volcanic action; lava closely underlies these breccias and tuffs. There is evidence of only one volcanic episode, which occurred in all cases after the Zaphrentis beds had been laid down, and before the strata characterised by Chonetes and Streptorhynchus were deposited. The lavas are olivine-dolerites or basalts, with phenocrysts of olivine or augite. They are frequently amygdaloidal, and in the variolites highly-altered felsparphenocrysts occur. The rocks vary in grain. The tuffs are all calcareous, and most are best described as "ashy limestones." The bulk of the lapilli varies from one-hundredth part of the rock to about one-third, and their composition is related to that of the basaltic lavas of the district.-The Rhætic beds of England, by Mr. A. Rendle short. The paper opens with a description of four new exposures of these rocks; one at Redland rests upon Carboniferous Limestone; a second is at Stoke Gifford, with a continuous, welldeveloped landscape-marble, the insect bed, and no bone bed; a third at Cotham Road (Bristol) yields baryta, celestine, and Naiadita at horizons containing no other fossils; and the fourth, at Aust, has given measurements of the uppermost 13 feet. An account is given of the constituent beds, with reference to the conditions of deposition.

\section{PARIS.}

Academy of Sciences, December 28, 1903.-M. Albert Gaudry in the chair.-M. Troost was elected a vice-president for the year 1904.--Researches on the density of chlorine, by MM. H. Moissan and Binet du Jassoneix (see p. 233).--On some new syntheses effected by means of molecules containing the methylene group associated with one or two negative radicals. The action of epichlorhydrin upon the sodium derivative of acetylacetone, by MM. A. Haller and G. Blanc. The reaction between epichlorhydrin and sodium acetylacetone is distinguished from the reactions between epichlorhydrin and the sodium derivatives of acetoacetic ester, benzoylacetic ester, and similar compounds by the fact that the chlorine reacts with the sodium, giving rise to products free from chlorine, one of which appears to be $\mathrm{CH}_{3} \cdot \mathrm{C}=\mathrm{CH}-\mathrm{CH}_{2}-\mathrm{CH} \cdot \mathrm{CH}_{2} \mathrm{OH}$. This changes spon-

taneously into a ketone, the constitution of which is under examination.-The potash soluble in the water of the soil and its utilisation by plants, by M. Th. schloesing, jun.On the first volume of the photographic catalogue of the sky published by M. A. Donner, director of the Observatory of Helsingfors, by M. Lœwy.-Remarks by M. R. Zeiller on the work of M. Michel Lévy on the fossil flora of the Tonkin Coal-measures.--Remarks by M. Alfred Picard on presenting his report on the Exhibition of 1900.-On the scapular and pelvic hands in the chondropterygian fishes, by M. Armand Sabatior.--On the limit of the Jurassic and Cretacean in the eastern part of the Pyrenees, and on the existence of two distinct epochs of formation of couzeranite limestones, by MM. Ch. Depéret and O. Mengel,-On the influence of the depth of immersion of a vessel on the speed, by $M . J . \Lambda$. Normand. A mathematical investigation into the relations existing between the weights of coal, engines, and other load, the maximum speed, displacement, and the exponent according to which the velocity varies in the neighbourhood of the maximum power.-On a property of functions, by M. H. Lebesgwe.-On linear partial differential equations, by M. J. Le Roux.-The convergence of periodic superposed roots, by M. Paul Wiernsberger.--On a new system of road traction called à propulsion continue, by M. Charles Renard. A description of a method of mechanically transmitting the power of a locomotive to a series of attached vehicles, the whole train forming a kind of articulated locomotive. The advantages gained are great precision in steering round corners, and a reduction in the weight of the locomotive, since the tractive power is not limited, as in the usual type, by the adhesion of its wheels. - New electromechanical arrangements of engagement and gradual change of velocity, by M. Paul Gasnier. A method of using an electrically driven motor by which its speed can be gradually varied from nothing to maximum as required. --On the extension of the Clapeyron formula to all indifferent states, by M. L. Ariès.--On the luminous intensity of stars and their comparison with the sun, by M. Charles Fabry. Measurements made on the intensity of the star Vega, near the zenith, in calm weather and at the sea-level, gave a value equal to a candle at 780 metres distance, or $x \cdot 7 \times 10^{-6}$ candles. A relation between magnitude of a star as usually measured by astronomers and the candlepower is then worked out.-On the difference of temperature of bodies in contact, by M. E. Rogovsky.-On sliding discharges, by M. J. de Kowalski.-On a diffusiometer, by M. J. Thovert. A modification of an instrument previously described, suitable for volatile liquids. The rate of diffusion is measured by the change in the refractive index of the liquid.--On a new method of preparing some anhydrous crystallised fluorides, by M. Defacqu. By heating a mixture of calcium chloride and manganese fluoride, the former being in excess, to $1000^{\circ}-1200^{\circ}$, crystallised calcium fluoride is obtained, either in cubes or octahedra.-Electrical osmosis in liquid ammonia, by M. Marcel Ascoli.-On the dissociation of alkaline carbonates, by M. P. Lebeau. Sodium carbonate, heated in a vacuum, is appreciably dissociated, the pressure of the carbon dioxide varying from $1 \mathrm{~mm}$. at $700^{\circ} \mathrm{C}$. to $4 \mathrm{I} \mathrm{mm}$. at $1200^{\circ} \mathrm{C}$. Similar measurements were also carried out with the carbonates of potassium, rubidium, and cæsium.-On the $\alpha$-amino-nitriles, by M. Marcel Delépine.-The combination of saccharose with some metallic salts, by M. D. Gauthier.-On the transformation of the primary a-glycols into the corresponding aldehydes, by M. Tiffeneau. A study of the mechanism of the transformation of $\left(\mathrm{CH}_{3}\right) \cdot\left(\mathrm{C}_{6} \mathrm{H}_{5}\right) \cdot \mathrm{C}(\mathrm{OH})-\mathrm{CH}_{2} \mathrm{OH}$ into $\left(\mathrm{CH}_{3}\right) \cdot\left(\mathrm{C}_{6} \mathrm{H}_{5}\right) \cdot \mathrm{CH} . \mathrm{CH}: \mathrm{O}$ by the action of $25^{\circ}$ per cent. sulphuric acid.- On the nitric esters of the acid alcohols, by M. H. Duval. Description of the preparation and properties of the nitrates of acetoxyacetic, lactic, $a$-oxybutyric, and glycollic acids. - The action of carbon dioxide upon aqueous solutions of aniline in the presence of nitrites, by M. Louis Meunier. An aqueous solution of aniline mixed with sodium nitrite gives diazoamidobenzene in presence of carbonic acid. Silver nitrite with aniline gives the silver salt of diazoamidobenzene. There is no reaction between sodium nitrite and aniline in aqueous solution in the absence of carbon dioxide.-On the retrogradation of starch, by M. 1. Maquenne.-The preparation of hydrogenated alcohols of the aromatic series, by M. Léon Brunel. By the action of hydrogen in the presence of reduced nickel at $170^{\circ}-200^{\circ} \mathrm{C}$., phenol gives cyclohexanol, thymol, hexahydrothymol, and carvacrol hexahydrocarvacrol.-On the oxidation of guaiacum by laccase, by M. Gabriel Eertrand. -The development of annual plants: study of the mineral bases, by M. G. André-- On the culture of sarrasin in the presence of a mixture of algæ and bacteria, by MM. Eouilhac and Giustiniani.--The evolution undergone by fishes of the genus Atherina in fresh and brackish water, by M. Louis Roule.-New facts on the $n$-rays of physiological origin, by M. Augustin Charpentier. The emission of the $n$-rays by living bodies is not peculiar to man; it has been found in rabbits, frogs, and other animals. The most important part of the physiological emission of the $n$-rays

NO. I 784 , VOL. 69] 
appears to take place in the nervous system, especially in the nerve centres.-The determination of the perceptible minimum and the duration of luminous perception in persons of weak sight, by M. S. Durand.-On mountain sickness, by $M$. Kronecker, - On the modifications induced in the respiration by the altitude of Mt. Blanc, by M. J. Vallot. The relation between the volume of air respired and the time spent at the summit is shown graphically, and also the variation in the weight of air breathed.-On a relation between the work and the so-called statical work equivalent on the ergograph, by M. Charles Henry and Mlle. J. loteyko.-Researches on the róle of the interstitial gland of the testicle. Experimental compensating hypertrophy, by MM. P. Ancel and P. Bouin.-Phototropism in the higher Artiozoa, by M. Georges Bohn.-The action of anethol upon the organism, by MM. E. Varenne, J. Roussel and L. Godefroy. Anethol shows no toxic effects, and may be safely used as a therapeutical agent.The action of radium upon different tissues, by $\mathrm{M}$. J. Danysz. The tissues, and especially the epithelial tissues of young animals, are much more sensitive to the action of radium rays than the tissues of adults. - On a consequence of cross-fertilisation, by M. Leclerc du Sablon.-On a true hybrid of chasselas by Ampelopsis hederacea, by M. Grille. -On the role of calcium oxalate in the nutrition of plants, by M. Amar. The lime (in the form of nitrate) necessary to the constitution of the plant is entirely assimilated up to a certain proportion, depending on the species; above this proportion the excess of lime is eliminated in the form of crystals of calcium oxalate.-On a disease of the leaves of the tobacco plant, by M. H. Bouygues,-On the Glacial deposits of the Garonne, by M. L. A. Fabre.-The geology of the western Alps, by M. Émile Haug.-Contribution to the study of the basaltic rocks of East Africa, by M. H. Arsandaux.-On the lakes of the Upper Engadine, by M. André Delebecque.- On the relation which exists between the proportion of gluten contained in different wheats and the proportion of total nitrogenous materials, by M. E. Fleurent.

\section{DIARY OF SOCIETIES.}

THURSDAY, JANUARY 7 .

Royal Institution, at 3.-Extinct Animals: Prof. Ray Lankester, F.R.S.

Röntgen Society, at 8.30.-The Revelations of Radium: Dr. G. B. Batten

FRIDAY, JANUARY 8

Royal Astronomical Society, at 5. -Transformation of Hansen's Tables: P. H. Cowell. - Note on the Use of Long Focus Mirrors for Eclipse Work: H. H. Turner.-New Double Stars detected with the 171 inch Reflector during the Year 1903 : Rev. T. E. Espin.-Ephemeris for Physical Observations of Jupiter. rgo4-5: A. C. D. Crommelin."The Rotation Period of Saturn in rgo3: W. F. Denning.-The "Great" Magnetic Storms, 1875 to 1903 , and their Association with Sun-spots, as Recorded at the Royal Observatory, Greenwich, communicated by the Astronomer Royal: E. W. Maunder. - juggested Connection between Sun-spot Activity and the Secular Change in Magnetic Declination: Mrs. E. W. Maunder-On the Chromatic Correction of Jbject Glasses: A. E. Conrady.-The Aurora and Magnetic Disturbance: William Ellis.-And, time permitting, Discussion on Methods of Reproduciag Astronomical Photograpis.

Royal Geographical Societr, at 4,-Adventures in Antarctic Lands and Seas: Lieut. Ernest Shackleton. (Lecture to Young People.)

SATURDAY, JANUARY 9 . Royal Institution, at 3.-Extinct Animals: Prof. Ray Lankester,
F.R.S.

MONDAY, JANUARY II.

Royal Geographical Society, at 8.30.--Exploration on the Southern Abyssinian Border: Captain Philip Maud.

Victoria Institute, at 4.30-Ancestral Worship: Rev. Arthur Elwin.

$$
\text { TUESDAY, JANUARY } 12 .
$$

Royal INSTITUTION, at 5.-The Development and Transformations of Animals : Prof. L. C. Miall, F.R.S.

Institution of Civil ENGineERs, at 8.-The Electrical Re-construction of the South London Tramways on the Conduit System: Alexander
Millar.

\section{WEDNESDAY, JANUARY I3.}

Society of ARTs, at 5.-Navigation of the Air: Eric S. Bruce. NO. 1784 , VOL. 69]

\section{THURSDAY, JANUARY I4.}

Institution of Electrical Engineers, at 8.-The City and South London Railway; Working Results of the Three Wire System applied to Traction, \&c. : P. V. McMahon. (Adjourned discussion.)-On the Magnetic Dispersion in Induction Motors, and its Influence on the Design of these Machines: Dr. Hans Bebrn-Eschenburg.

Roval Institution, at 5.-The Flora of the Ocean: G. R. M. Murray F R.S.

Mathematical Society, at 5.30.-On Various Systems of Piling: Prof J. D. Everett.-The Differential Equation

$$
\frac{\partial^{2} \mathrm{~V}}{\partial x_{1}^{2}}+\frac{\partial^{2} \mathrm{~V}}{\partial x_{2}{ }^{2}}+\ldots+\frac{\partial^{2} \mathrm{~V}}{\partial x_{n}{ }^{2}}=0:
$$

H. Bateman. - On the Notion of Lines of Curvature in the Theory of Surfaces: Dr. G. Prasad.-On Groups of Order $p^{\alpha} q \beta$ : Prof. W.

Society of ARTS, at 4.30.-The Presidency of Bombay: Sir William LeeWarner. K.C.S.I.

$$
\text { FRIDAY, JANUARY I5. }
$$

Roval Institution, at 9.-Shadows : Lord Rayleigh.

Institutian of Mechanical ENGineERs, at 8.

SATURDAY, JANUARY $x 6$.

Royal Institution, at 3.-British Folk Song: J. A. F. Maitland.

\section{CONTENTS.}

PAGE

The Critical State. By M. W. T. 217

The B.M. Hand-List of Birds and Catalogue of Eggs. By R. L. . . . Modern Science Popularised. By G. H. B. ... . 219 Applied Psychology. By W. McD. . . . . . . . 219 Our Book Shelf :-

Jordan, Kellogg, and Heath: "Anima Studies a Text-book of Elementary Zoology for Use in High Schools and Colleges."-J. A. T.

Auerbach: "Das Zeisswerk und die Carl-ZeissStiftung in Jena"

Woods : "Reasons Against the Theory of Evol :

Higgins. " Lessons in Physics"

Dodd : "The Certainty of a Future Life in Mars"

Fenneman: "On "22I Wisconsin"- $-\mathrm{E}, \mathrm{W}$ Lakes of South-eastern

Giglioli : "Malessere Agrario ed A * . . 222

Letters Alimentare in Italia" 222

Does the Radio-activity of Radium depend upon its Concentration?--Prof. E. Rutherford, F.R.S.

Relative Motion and Conservation of Energy.-Prof. G. H. Bryan, F.R.S.

The Universities and Technical Education.-Prof. W. R. Fisher.

Prof. Johannsen on Herenity.-G. Udny Yule; The Reviewer . . Prof The Heat of Radium.-Prof. Edmund J. Milis, F.R.S

Rocket Lightning.-W'. A. 'Lee; Prof. 'J. D. Everett, F.R.S.

The Recent Leonid Shower 'J 'J R . . . . 224 Tentral A sian Leonid Shower.-John R Henry . 224 Water Supply and Irriga.ion in the United S. H. 225 (Illustrated.)

The Work of the Reichsansial . . . . . . . 226 Recent Geological Obsanstalt . . . . . . 228 Recent Geological Observations in Cape Colony. By G. A. J. C. . . . . . . . . . 229 The Climate of South America. By W. J. S. L. . 230 Our Astronomical Column :- . . . . . . 230

Astronomical Calendars for 1904 . . . . . . . . 233

The Variable Star 1921, W Aurigæ . . . . . . . . 233

Light Economy in Spectrum Photography. . . . . 234

Iniensity of the Sun's Light _. . . . . . . . . . 234

Prizes Proposed by the Paris Academy of Sciences

for I904 . . . . . . . . . . . . . . . . . . 234

Research Grants of the Carnegie Institution . . . 235

Survey of Scottish Lakes. . . . . . . . 236

The Senescence of Organs and its influence on

Pathological Phenomena . . . . . . . . . 237

University and Educational Intelligence . . . . . . 237

Societies and Academies . . . . . . . . . . . 238

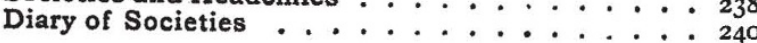

